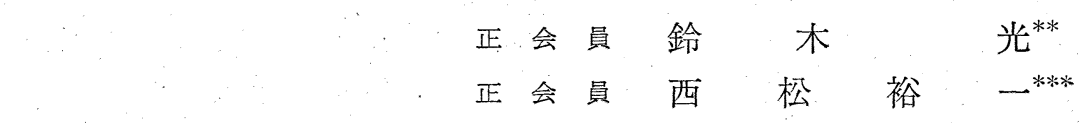

\title{
On the Cutting Force of Rock and Cement Mortar (2nd Report)
}

Kō SUZUKI and Yūichi NISHIMATSU

In the first report, the authors reported some results of the cutting experiments of a tuffaceous sandstone and a cement mortar. The authors shaw that the relations of the cutting force and the cutting depth are given by the equations,

$$
\left.\begin{array}{l}
P=a_{1}+b_{1} t \\
Q=a_{2}+b_{2} t
\end{array}\right\}
$$

and discussed on the second term of these equations.

In this second report, the authors discuss on the first term of the equation (I), and deduce the presence of the over-cutting, as sometimes observed in the metal cutting.

Finally it is concluded that the cutting force with the blunted cutting tool is represented by the following equations

$$
\begin{aligned}
& \left.P=\frac{4}{n+1} \cdot S_{t} \cdot \sin k \cdot\left\{\frac{\cos (\delta+\phi) \cdot\left(d+d_{0}\right)}{1-\cos (k-\delta-\phi)}+\frac{\cos (\alpha-\phi) \cdot(t-d)}{1-\cos (k+\alpha-\phi)}\right\}\right) \\
& \left.Q=\frac{4}{n+1} \cdot S_{t} \cdot \sin k \cdot\left\{\frac{\sin (\delta+\phi) \cdot\left(d+d_{0}\right)}{1-\cos (k-\delta-\phi)}+\frac{\sin (\phi-\alpha) \cdot(t-d)}{1-\cos (k+\alpha-\phi)}\right\}\right\} \\
& d: \text { the height of blunt end } \\
& \quad d_{0}: \text { the depth of over-cutting } \\
& \delta: \text { the rake angle of blunt end }
\end{aligned}
$$

Some results of this cutting experiment suggest the presence of the "built-up wedge" of the cutting tool, though this phenomenon could not be approved.

\section{1. 緒言}

鈍い刃先を有する直刃ビットで岩石およびセメントモ ルタルの二次元切削実験を行ない，このような場合の破 壊機構について考察した結果, 刃先付近に圧砕帯が発生 すること, 切削抵抗の主分力 $P$ および背分力 $Q$ と切込深 さ $t$ との間の関係式として, 縦軸 $(\mathrm{P}$ 軸または $\mathrm{Q}$ 軸) を 十側で切る直線の式

$$
\left.\begin{array}{l}
P=a_{1}+b_{1} t \\
Q=a_{2}+b_{2} t
\end{array}\right\}
$$

が成立することなどについては，第1 報1)で述べた。

(1) 式の定数部分 $a$ の值は，かなり大きく, 切込深さ が数mm 程度の場合は，全切削抵抗の50\%前後に達する 場合もある。したがつて定数部分 $a$ の值に影響する要因 を解明することは，切削機構を解明する上からばかりで なく，実用的にも重要であると考えられる。鈍い刃先を 有する刃物の切削抵抗については，I. EVANs ${ }^{2)}$ が考察

\footnotetext{
* 昭和 43 年 3 月 5 日受理

** 工博 東京大学教授 工学部資源開癹工学科

**** 東京大学助教授 工学部資源開発工学科
}

Vol. 84 No. 967 ('68-11)
しているが，本報では特に切込深さが小さい場合につい て二次元実験を行ない，第 1 報の実験結果と合わせて, この定数部分 $a$ の值に影響する要因について考察し, 鈍 い刃先を有する刃物の切削抵抗を求める計算式について のべる。

\section{2. 刃先の圧砕帯の影響}

すでにのべたように砂岩及びセメントモルタルを直刃 ビットで切削した場合, 刃先付近に圧砕帯が発生する。 第1 報でのべたように(1) 式の比例部分すなわち第 2 項が，大きな切屑の発生に関係する項であるとすると， 第 1 項すなわち定数部分 $a$ は, 刃先の圧砕帯に関する項 であると考えられる。このよらに考えるとまず問題にな るのは圧砕帯の上端の位置である。圧砕帯の上端の位置 は，肉眼観察によつては正確に知ることができなかつた が, 刃先の削り落し部分の上端（第 1 図のB点）付近に あることが認められた。

ここでは圧砕帯の上端と刃先の削り落し部分の上端が 一致し，大きな切屑を生成する割れ目もこの点から出発 すると考えることにする。 


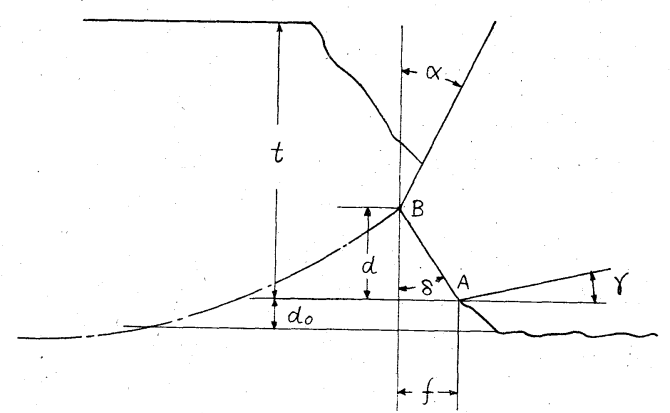

第 1 図刃物の形状と記号

そして (1) 式を少し変形して

$$
\left.\begin{array}{l}
P=\left(a_{1}+b_{1} d\right)+b_{1}(t-d) \\
Q=\left(a_{2}+b_{2} d\right)+b_{2}(t-d)
\end{array}\right\}
$$

と書き直し, (2) 式の第 1 項は, 第 1 図 $\mathrm{B}$ 点より下方の 領域での破壊に関する項であり，第 2 項は同じく $\mathrm{B}$ 点よ り上方の領域での破壊に関する項であると仮定する。

第 1 報の第 3 表に示した各定数の值を用いて，(2) 式 の第 1 項

$$
\left.\begin{array}{l}
P_{0}=a_{1}+b_{1} d \\
Q_{0}=a_{2}+b_{2} d
\end{array}\right\}
$$

の值を計算した結果を第 1 表に示す。これから物すく い角 $\alpha$ が， $P_{0}$ および $Q_{0}$ にほとんど影響を及ぼさないこ とがわかるであるう。

第1表に示した通り，実験に使用した刃物の刃先削り 落し角 $\delta$ (第 1 図参照) は，いろいろであるがその大部 分は $13^{\circ} \sim 14^{\circ}$ であるので, このような刃先削り落し角を 有するもののみについて, 削り落し高さ $d$ と第 1 表に示 した $P_{0}$ および $Q_{0}$ の関係を図示したのが，第 2 図および 第 3 図である。

これからわかる通り刃先削り落し高さ $d$ と $P_{0}$ あるい は $Q_{0}$ の関係は，ばらつきが大きいためあまり明瞭でな

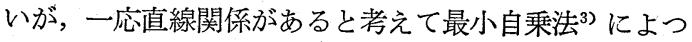
て係数を決定すると，

\begin{tabular}{|c|c|c|c|c|c|c|c|}
\hline \multicolumn{2}{|r|}{$刃$} & 形 & 状 & 青 & 石 & \multicolumn{2}{|c|}{ セメントモルタル } \\
\hline$\alpha^{\circ}$ & $d \mathrm{~mm}$ & $f \mathrm{~mm}$ & $\delta^{\circ}$ & $\begin{array}{c}P_{0} \\
\mathrm{~kg} / \mathrm{cm}\end{array}$ & $\begin{array}{c}Q_{0} \\
\mathrm{~kg} / \mathrm{cm}\end{array}$ & $\begin{array}{c}P_{0} \\
\mathrm{~kg} / \mathrm{cm}\end{array}$ & $\begin{array}{c}Q_{0} \\
\mathrm{~kg} / \mathrm{cm}\end{array}$ \\
\hline $10^{\circ}$ & $\begin{array}{l}0.15 \\
0.57 \\
0.69 \\
1.13\end{array}$ & $\begin{array}{l}0.11 \\
0.13 \\
0.17 \\
0.29\end{array}$ & $\begin{array}{l}36^{\circ} 12^{\prime} \\
13^{\circ} 08^{\prime} \\
13^{\circ} 43^{\prime} \\
14^{\circ} 18^{\prime}\end{array}$ & $\begin{array}{l}28.2 \\
36.8 \\
39.4 \\
44.1\end{array}$ & $\begin{array}{r}14.9 \\
21.8 \\
25.2 \\
-\end{array}$ & $\begin{array}{l}32.2 \\
35.3 \\
38.4 \\
43.3\end{array}$ & $\begin{array}{r}13.1 \\
18.2 \\
24.8 \\
\end{array}$ \\
\hline $20^{\circ}$ & $\begin{array}{l}0.17 \\
0.38 \\
0.71 \\
1.10\end{array}$ & $\begin{array}{l}0.14 \\
0.09 \\
0.17 \\
0.28\end{array}$ & $\begin{array}{l}38^{\circ} 45^{\prime} \\
12^{\circ} 42^{\prime} \\
13^{\circ} 16^{\prime} \\
14^{\circ} 10^{\prime}\end{array}$ & $\begin{array}{l}26.5 \\
26.6 \\
40.8 \\
42.9\end{array}$ & $\begin{array}{r}16.0 \\
18.4 \\
29.8\end{array}$ & $\begin{array}{l}27.9 \\
11.1 \\
43.7 \\
38.8\end{array}$ & $\begin{array}{r}12.4 \\
8.3 \\
22.5 \\
21.8\end{array}$ \\
\hline $30^{\circ}$ & 0.17 & 0.14 & $38^{\circ} 00^{\prime}$ & 21.2 & 14.7 & 26.1 & 17.4 \\
\hline $40^{\circ}$ & $\begin{array}{l}0.21 \\
0.46 \\
0.56 \\
0.92\end{array}$ & $\begin{array}{l}0.08 \\
0.11 \\
0.13 \\
0.23\end{array}$ & $\begin{array}{l}19^{\circ} 22^{\prime} \\
14^{\circ} 02^{\prime} \\
13^{\circ} 11^{\prime} \\
13^{\circ} 54^{\prime}\end{array}$ & $\begin{array}{l}17.8 \\
28.5 \\
42.9 \\
44.8\end{array}$ & $\begin{array}{r}14.1 \\
27.2 \\
=\end{array}$ & $\begin{array}{l}27.3 \\
25.5 \\
32.4 \\
37.6\end{array}$ & $\begin{array}{r}15.2 \\
18.0 \\
20.7\end{array}$ \\
\hline
\end{tabular}

第1表 刃先削り落し部の寸法と切削 抵抗の定数部分の值

$1570\langle 2\rangle$

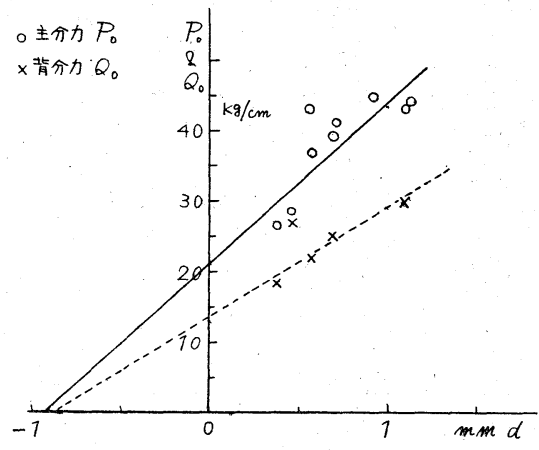

第 2 図刃先削り落し角 $\delta=13 \sim 14^{\circ}$ の場合 の定数部分 $P_{0}$ 执よび $Q_{0}$ と刃先削 り落し高さ $d$ との関係——青石

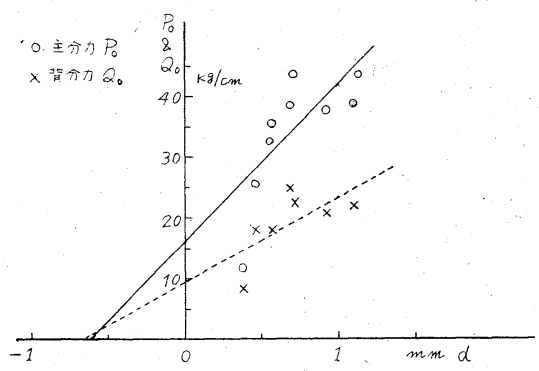

第 3.図 刃先削り落し角 $\delta=13 \sim 14^{\circ}$ の場合の定 数部分 $P_{0}$ および $Q_{0}$ と刃先削り落し高 さ $d$ との関係一七メントモルタル

青石については*

$$
\left.\begin{array}{l}
P_{0}(\mathrm{~kg} / \mathrm{cm})=21.1+22.5 d(\mathrm{~mm}) \\
Q_{0}(\mathrm{~kg} / \mathrm{cm})=13.1+15.7 d(\mathrm{~mm})
\end{array}\right\}
$$

セメントモルタルについては

$$
\left.\begin{array}{l}
P_{0}(\mathrm{~kg} / \mathrm{cm})=16.2+26.0 d(\mathrm{~mm}) \\
Q_{0}(\mathrm{~kg} / \mathrm{cm})=9.7+13.7 d(\mathrm{~mm})
\end{array}\right\}
$$

が得られで*，いずれも $d=0$ の場合，すなわち完全に 鋭い刃先を有する刃物でも (2) 式の第 1 項が 0 にならな い。このことは鋭い刃先を有する刃物でも刃先の圧砕部 が消滅しないことを推測させる。

\section{3. 過切削現象の存在}

前に (2) 式の第 1 項, すなわち $P_{0}$ および $Q_{0}$ は刃先の 圧砕帯に関係する切削抵抗であり, 刃先の圧砕帯の上端 は刃先の削り落し部分の上端（第 1 図のB点）であると 考えた。他方 (4) 式および (5) 式から，鋭い刃先を有す る刃物でも圧砕帯が存在すると推測されるとのべた。そ してこのような現象は肉眼観察の結果から考えても大い

* 片寄りの特に著しい $\left(d=0.56, P_{0}=42.7\right)$ 拮よび $(d=0.46$, $\left.Q_{0}=27.2\right)$ はあてはめの計算から除外した。

**（3)式と(4)㧊よび (5) 式は形式的には同じであるが全く別の式 である。すなわち (3) 式は実験結果から $P_{0}$ および $Q_{0}$ を算出 するための式であつて， $P_{0}$ あるいは $Q_{0}$ と刃先削り落し高さ $d$ の関係を表わす式ではない。 
にあり得べきことのように思われる。また切削によつて 作られた新しい自由面には一種の擦過痕が顕著に観察さ れる。

いま, 刃先の圧砕帯が切込深さ $t$ の線より下方，すな わち第 1 図のA点より下方にまで延びていて，いわゆる 過切削現象が存在すると仮定すると，これらを矛盾なく 説明することができる。

またもし過切削現象が存在すれば，(4) 式および (5) 式で $P_{0}$ および $Q_{0}$ が 0 になる深さが, 真の切込み深さ であり，したがつてまた圧砕帯の下端であろう。その場 合，第 1 図のA点を基準にして測つたこの深さ $d_{0}$ を仮 に過切削深さと名付けることにすれば， $d=-d_{0}$ で $P^{0}$ も $Q_{0}$ も 0 になるはずである。換言すれば，(4) 式およ び (5)式で $P_{0}$ を表わす直線が横軸を切る点と， $Q_{0}$ を表 わす直線が横軸を切る点とが一致し，一般に

$$
\left.\begin{array}{l}
P_{0}=b_{p}\left(d+d_{0}\right) \\
Q_{0}=b_{q}\left(d+d_{0}\right)
\end{array}\right\}
$$

が成立するはずである。

(4) 式および (5) 式をそれぞれ第 2 図および第 3 図に 記入すると， $P_{0}$ を表わす直線 (実線) と $Q_{0}$ を表わす直 線（破線）とがほぼ同じ位置で横軸を切ること，すなお ち(6) 式がほぼ成立することがわかる。この過切削深さ $d_{0}$ の值は，第 2 表に示すとおりである。

\begin{tabular}{|c|c|c|}
\hline & 青 & セメントモルタル \\
\hline $\begin{array}{l}\text { 主分力 } P_{0} \text { より算出 } \\
\text { 分力 } Q_{0} \text { より算出 }\end{array}$ & $\begin{array}{l}0.94 \mathrm{~mm} \\
0.84\end{array}$ & $\begin{array}{l}0.62 \mathrm{~mm} \\
0.71\end{array}$ \\
\hline 均 & 0.88 & 0.67 \\
\hline
\end{tabular}

第 2 表 過切削深さ $d_{0}$ の值

\section{4. 切込深さが小さい場合の切削抵抗}

以上は第 1 報で報告した実験，すなわち切込深さ 2 $\mathrm{mm}$ 以上で行なつた実験の結果からの推論であつて，い わば外插的な推論であつた。またこれまでの結果から

は，(6) 式の比例定数 $b_{p}$ および $b_{q}$ の值を決定する要因 については，なにも知ることができない。

このような問題点を明らかにするため, 種々の刃先削 り落し角 $\delta$ と削り落し高さ $d$ とを有する刃物を用いて, 切込深さが $2 \mathrm{~mm}$ 以下の範囲で，第 1 報で報告したと同 様な二次元切削実験を行なつた。

この実験に使用した刃物の諸元を第 3 表に, 被切削材 料の強度特性を第 4 表に示す*。

第 3 表 闶物の形状

\begin{tabular}{c|c|c|c}
\hline$\alpha^{\circ}$ & $d \mathrm{~mm}$ & $f \mathrm{~mm}$ & $\delta^{\circ}$ \\
\hline \multirow{4}{*}{10} & 1.13 & 0.29 & 14 \\
& 1.17 & 0.54 & 25 \\
& 1.83 & 0.80 & 24 \\
& 1.73 & 1.83 & 46 \\
\hline \multirow{4}{*}{40} & 0.92 & 0.23 & 14 \\
& 0.89 & 0.42 & 25 \\
& 1.85 & 0.78 & 23 \\
& 1.69 & 1.76 & 46 \\
\hline
\end{tabular}

\begin{tabular}{|c|c|c|c|}
\hline \multirow[b]{2}{*}{ ブロック番号 } & \multirow[t]{2}{*}{ 青石 } & \multicolumn{2}{|c|}{$\left(\begin{array}{c}\text { セメンールタル } \\
(\mathrm{C}: \mathrm{S}: W=1: 4: 1)\end{array}\right.$} \\
\hline & & B4 & B5 \\
\hline $\begin{array}{c}\text { 王覆強度 } S_{c} \\
\mathrm{~kg} / \mathrm{cm}^{2}\end{array}$ & 373 & 124 & 150.5 \\
\hline$\underset{\mathrm{kg} / \mathrm{cm}^{2}}{\text { 引張強度 }} S_{t}$ & 51.8 & 12.4 & 18.7 \\
\hline ぜい性度 $B r$ & 7.2 & 10.0 & 8.0 \\
\hline
\end{tabular}

第 4 表 被切削材料の強度特性

実験結果は，第 4 図および第5 図に示すとおりであ る。

いま，このように切込深さが小さく，すくい角が負の 場合についても**筆者らの切削抵抗計算式，すなわち

$$
\left.\begin{array}{r}
P=C_{1}+\frac{4}{n+1} \cdot S_{t} \cdot t \cdot \\
\frac{\sin k}{1-\cos (k+\alpha-\phi)} \cos (\alpha-\phi) \\
Q=C_{2}-\frac{4}{n+1} \cdot S_{t} \cdot t \cdot \\
\frac{\sin k}{1-\cos (k+\alpha-\phi)} \sin (\alpha-\phi)
\end{array}\right\}
$$

が成立し，さらに前節でのべた過切削現象がつねに存在 すると考える。

このよらに考えると，第 4 図および第 5 図に示した実 験結果に，(6) 式と同じ形の式

$$
\left.\begin{array}{l}
P=b_{p}\left(t+d_{0}\right) \\
Q=b_{q}\left(t+d_{0}\right)
\end{array}\right\}
$$

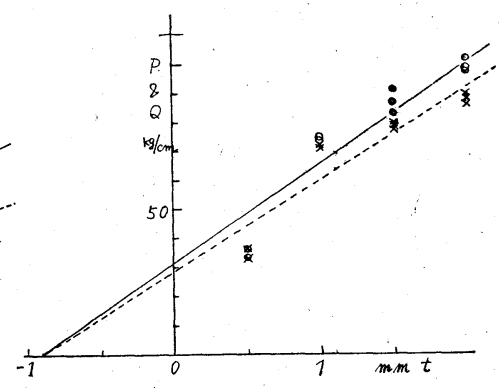

(c) $\delta=46^{\circ}$

（c）刃先削り落し角マイナス $46^{\circ}$

(a) 刃先削り落し角マイナス $14^{\circ}$

(b) 刃先削り落し角マイナス $23^{\circ}$ 〜マイナス $25^{\circ}$ 青石

* 青石は第 1 報に使用したるのと同じブロックから作製した試料 を用いている。
**ここの場合は刃先削り落し面か刃物すくい面となるから $\alpha=$ ○ である。 


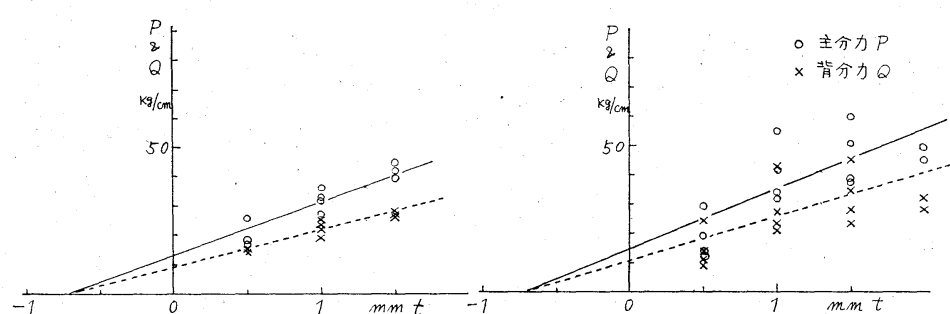

(a) $\delta=14^{\circ}$

(a) 成先削り落し角マイナス $14^{\circ}$ (b) $\delta=23^{\circ} \sim 25^{\circ}$

(b) 刃先削り落し角マイナス $23^{\circ}$ 〜マイナス $25^{\circ}$

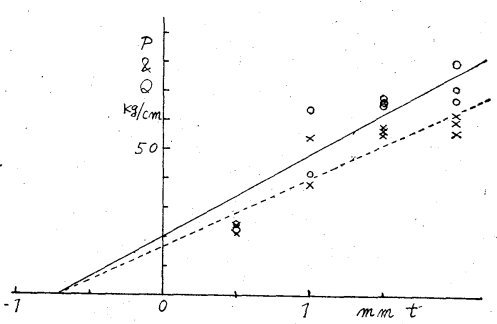

(c) $\delta=46^{\circ}$

(c) 刃先削り落し角マイナス $46^{\circ}$

第 5 図切削抵抗と切込深さの関係一七メントモルタル

をあてはめて，第 1 報と同様に

$$
\begin{aligned}
& b_{q} / b_{p}=-\tan (\alpha-\phi) \\
& b_{p}=\frac{4}{n+1} \cdot S_{t} \cdot \frac{\sin k}{1-\cos (k+\alpha-\phi)} \\
& \cos (\alpha-\phi)
\end{aligned}
$$

を用いて，摩擦角 $\phi$ と応力分布指数 $n$ とを求めることが できる。この場合刃先削り落し角 $\delta$ が異なれば，過切削 深さ $d_{0}$ も異なる可能性があるが，ここでは仮に青石に ついては常に $d_{0}=0.9 \mathrm{~mm}$ ，セメントモルタルについて は常に $d_{0}=0.7 \mathrm{~mm}$ とおいて, 計算することにした。結 果は第 6 図および第 7 図に示すとおりである。これらの グラフには，第 1 報に示した計算結果も再び示してあ る。

ここで (8) 式は, 一定の刃先削り落し高さを有する刃

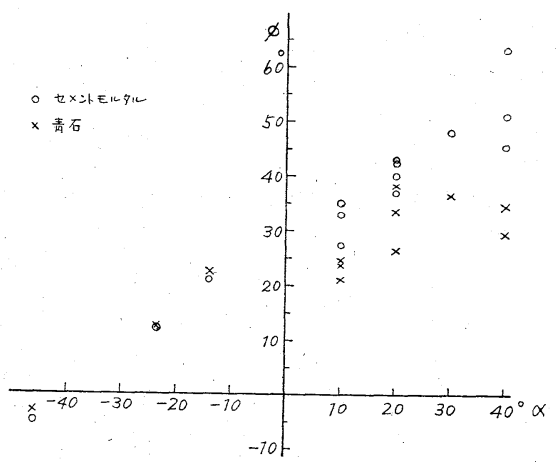

第6 図 摩擦角 $\phi$ と刃物すくい角 $\alpha$ の関係

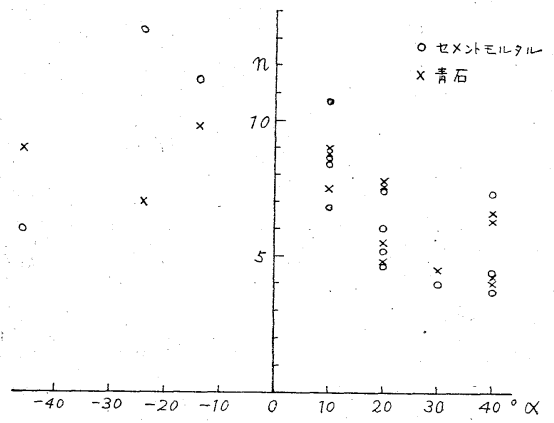

第7図 応力分布指数 $n$ と刃物すくい角 $\alpha$ の関係
物で，切込深さを種々に変えた場合の切削抵抗の式であ り，これに対して (6) 式は，種々の刃先削り落し高さを 有する刃物で, 切込深さが，その刃先削り落し高さと等

しくなつたときの切削抵抗を表わす式である。

いま刃先削り落し角 $\delta=14^{\circ}$ の刃物で青石を切削した 場合の (8) 式, すなわち

$$
\left.\begin{array}{l}
P(\mathrm{~kg} / \mathrm{cm})=18.8(t+0.9 \mathrm{~mm}) \\
Q(\mathrm{~kg} / \mathrm{cm})=14.0(t+0.9 \mathrm{~mm})
\end{array}\right\}
$$

を（4）式*と比較すると，各パラメータの值がかなり近 似していることがわかる**これは圧砕帯の切削抵抗につ いても，一般に (7) 式があてはまることを暗示するもの である。

\section{5. 結 論}

第 1 報においては, 切削抵抗の式

$$
\left.\begin{array}{l}
P=P_{0}+b_{1}(t-d) \\
Q=Q_{0}+b_{2}(t-d)
\end{array}\right\}
$$

の第 2 項について主として論じたが，本報においては， 専ら第 1 項について考察した。

まず $P_{0}$ あるいは $Q_{0}$ の值と，刐物すくい角 $\alpha$ の大き さとが無関係であることを知り，つぎに刃先削り落し高 さ $d$ と $P_{0}$ および $Q_{0}$ の関係を考察し, 実際には切込深 さ $t$ より下方まで切削が行なわれていること，すなわち 過切削現象が存在することを推論した。

新たに，切込深さが小さく，为物すくい角が負の場合 について二次元切削実験を行ない，この場合にも過切削 現象の存在を仮定すると，筆者らの式すなおち (7) 式を あてはめ得ることを示した。

さらに(7)式は，鈍い刃先を有する刃物の切削抵抗の らち在砕帯に関する項，すなわち (2) 式の第 1 項の值を 計算するためにも適用できるであろらことをのべた。

したがつて本報および第 1 報で報告した実験条件の下 では，第 1 図に示したよらな鈍い刃先を有する刃物の切 削抵抗を表わす式として，

*これがこの場合の (6) 式に相当する。

** セメントモルタルについては各ブロックこととに強度特性が異な るため，同㥞の検討をすることができない。 


$$
\begin{gathered}
P=\frac{4}{n+1} \cdot S_{t} \cdot \sin k \\
\left\{\frac{\cos (\delta+\phi)\left(d+d_{0}\right)}{1-\cos (k-\delta-\phi)}\right. \\
\left.\quad+\frac{\cos (\phi-\alpha)(t-d)}{1-\cos (k+\alpha-\phi)}\right\} \\
Q=\frac{4}{n+1} \cdot S_{t} \cdot \sin k \\
\left\{\frac{\sin (\delta+\phi)\left(d+d_{0}\right)}{1-\cos (k-\delta-\phi)}\right. \\
\left.\quad+\frac{\sin (\phi-\alpha)(t-d)}{1-\cos (k+\alpha-\phi)}\right\}
\end{gathered}
$$

が成立するといえよう。

な敃第 6 図に示したよらに物すくい面と被切削材料 の間の見掛けの摩擦角 $\phi$ が，刃物すくい角 $\alpha$ の増加とと もに増加すること，さらに济切削現象の存在など, 金 属材料の切削において見られるよらな構成刃先 ${ }^{4}$ 之類似 した現象が，岩石類の切削でも存在することを想像させ るが，今回の実験ではこの点を確認することはできなか つた。

最後に実用的な面から言えば，切込深さを大きくする と (13) 式および (14) 式の第 1 項, すなわち圧研帯が切
削抵抗に及ぼす影響が，相対的に減少して，切削効率が 上昇することが予想される。

切込深さが大きいときの方が切削効率が高いことは， 石炭の場合についてはすでに指摘されていることで，そ の理由として切屃の比表面積の減少や強度の寸法効果な ぞが挙げられているが5)，その他に本実験の場合のよう に刃先圧砕部の影響が相対的に減少することも考えられ るであろら。

謝辞 本研究に関し, 試料の作製からデータの整理に 至るまで, 終始一貫して協力を惜しまれなかつた東京大 学工学部資源開発工学教室の秋山政雄技術員に厚く感謝 の意を表する。

\section{参若文献}

1）鈴木光・西松裕一: 岩石敊よびセメントモルタルの切剧抵抗 厄ついて(第 1 報)，日鈗誌，Vol. 84，No.961(1968) p. 548

2) I. Evans: The force to cut coal with blunt edges, Int. J. Rock Mech. \& Min. Sci., 2, 1 (March, 1965) p. 1/ 12

3) W. E. DeMING (森口繁一訳)：推計学炕るデータのまと 内方, 岩波書店 (1950)

4) 星光一：金属切削，工業調查会 (1960)

5) C. D. POMERó: The breakage of coal by wedge action, Coll. Guard., 207 (1963) p. $642 / 8$

\section{3 年度秋季大会分科研究会餈料頒布について}

大会資料（会誌 9 月号）を分冊してお頒けしております。必要記事簡便にご利用で きますので，お手許にお備え下さい。

最近における試錐の実状と諸問題….. 60 頁 $¥ 300$

岩石強度測定法に関する発表会 28 頁 $¥ 250$

深部採掘に関する諸問題 $\left.\begin{array}{l}\text { 採掘および掘進（とくに坑内）の機械化 } \\ \text { 鉱山のテレコントロール }\end{array}\right\}$ 86 頁 $¥ 300$

84 頁

$¥ 300$

機械採炭・自然発火対策 44 頁

$¥ 250$

新製錬法の可能性 62 頁 